\title{
Canada's first universal varicella immunization program: Lessons from Prince Edward Island
}

\author{
Lamont Sweet $\mathrm{MD}^{1}$, Peggy Gallant PHN ${ }^{1}$, Marie Morris PHN ${ }^{1}$, Scott A Halperin $\mathrm{MD}^{2}$
}

L Sweet, P Gallant, M Morris, SA Halperin. Canada's first varicella immunization program: Lessons from Prince Edward Island. Can J Infect Dis 2003;14(1):41-44.

A live attenuated varicella vaccine was licensed in Canada in December 1998. The first universal varicella immunization program in Canada was initiated in Prince Edward Island in 2000. Students in grades one to six without a history of varicella were offered the vaccine, administered by Public Health Nurses, in school clinics during February and March 2000. The acceptance rate ranged from $29.1 \%$ of all grade one students to $9.8 \%$ of all grade six students; overall, $18.8 \%$ of students received the vaccine. A universal program for children 12 months of age was introduced on April 1, 2000 and catch-up clinics for those between 12 months of age and those in grade one were introduced in June 2000. Repeated media announcements and the cooperation of staff in schools and daycare facilities assisted in informing parents about the availability of the vaccine. Vaccineassociated adverse events have been uncommon and the vaccine has been well accepted.

Key Words: Chickenpox; Chickenpox vaccine; Varicella; Varicella vaccine

\section{Premier programme canadien universel d'im- munisation contre la varicelle : l'expérience de l'Île-du-Prince-Édouard}

En décembre 1998, un vaccin vivant atténué antivaricelleux a été homologué au Canada. Le premier programme canadien universel d'immunisation contre la varicelle a été lancé à l'Île-du-Prince-Édouard en 2000. Le vaccin a été offert aux écoliers de la première à la sixième année sans antécédents de varicelle et a été administré par des infirmières de la santé publique dans des cliniques scolaires en février et en mars 2000. Le taux d'acceptation allait de 29,1\% de tous les écoliers de première année à 9,8\% de tous ceux de sixième année; globalement, 18,8\% des écoliers ont reçu le vaccin. Un programme universel à l'intention des enfants âgés de 12 mois a été lancé le $1^{\text {er }}$ avril 2000 et des cliniques de rattrapage pour ceux qui avaient plus de 12 mois, mais n'étaient pas encore en première année a été introduit en juin 2000. Les parents ont été informés de la disponibilité du vaccin grâce à des annonces répétées dans les médias et à la coopération du personnel des écoles et des garderies. Les manifestations indésirables associées au vaccin ont été peu fréquentes et le vaccin a été bien accepté.
$\mathrm{V}$ aricella is one of the most common human infections; nearly $95 \%$ of the Canadian population demonstrates serologic evidence of infection by adulthood (1-3). While most infections are mild and self limited, over 2000 hospitalizations occur annually in Canada as a result of varicella, with five to 10 deaths (3). Complications occur in $2 \%$ to $10 \%$ of cases, usually as bacterial infections such as cellulitis (4). Varicella is a major predisposing event for the development of invasive Streptococcus pyogenes (Group A streptococcus) infection; it is estimated that $15 \%$ of these infections could be prevented through the prevention of chickenpox (5). Varicella presents a substantial financial burden to Canadians; the cost of uncomplicated cases of chickenpox in Canada has been estimated to range from $\$ 236.50$ to $\$ 370.20$ per case (6). Complicated cases, although infrequent, were estimated to cost between $\$ 7060$ to $\$ 8398$ per case (7).

Varicella vaccine is recommended for all children at one year of age, and for any unimmunized children who have not had chickenpox (3,8). In 1999, Prince Edward Island (PEI), population 137,980 and a birth cohort of grades one to six students of 1910, experienced a province-wide outbreak of chickenpox. Four children were admitted to hospital, including two with secondary bacterial cellulitis requiring intravenous antibiotics; one child born prematurely who developed hemorrhagic chickenpox at five months of age; and one child with severe varicella hepatitis. A parent of one of these children lobbied the PEI Minister of Health and Social Services to provide chickenpox vaccine universally to children in the province. The Minister responded by reviewing the status of the vaccine and announcing Canada's first universal chickenpox vaccination program for all children between 12 months of age and those in grade six. The program was designed to include three phases - Phase 1, a catch-up program for all children who had not had chickenpox in grades one through six in the winter and spring of 2000; Phase 2, a universal program for all children at 12 months of age to begin April 1, 2000; and Phase 3, a catch-up program for all children age 12 months to those in grade one in 2000 to 2003 . The present article describes the Phase 1 program in which chickenpox vaccine was offered to 11,785 grade one to six children in PEI with no history of the disease.

\footnotetext{
${ }^{1}$ Department of Health and Social Services,Charlottetown, Prince Edward Island; ${ }^{2}$ Dalhousie University and the IWK Health Centre, Halifax, Nova Scotia

Correspondence and reprints: Dr Lamont Sweet, Prince Edward Island Department of Health and Social Services, PO Box 2000, Charlottetown, Prince Edward Island C1A 7N8. Telephone 902-368-4996, fax 902-368-4969, e-mail lesweet@gov.pe.ca Received for pulication April 24, 2001. Accepted February 4, 2002
} 
TABLE 1

Actual and estimated susceptible proportion of Prince Edward Island students receiving varicella vaccine by grade during February and March 2000

\begin{tabular}{|c|c|c|c|c|c|}
\hline \multirow[b]{2}{*}{ Grade } & \multicolumn{2}{|l|}{ Actual uptake } & \multicolumn{3}{|c|}{ Estimated uptake by susceptibles } \\
\hline & $\begin{array}{l}\text { Number of } \\
\text { students }\end{array}$ & $\begin{array}{c}\text { Number } \\
\text { immunized (\%) }\end{array}$ & $\begin{array}{c}\text { Estimated \% } \\
\text { susceptible (1-3) }\end{array}$ & $\begin{array}{l}\text { Calculated number } \\
\text { susceptible* }\end{array}$ & $\begin{array}{l}\text { of susceptibles } \\
\text { immunized }^{\dagger}\end{array}$ \\
\hline 1 & 1938 & $563(29)$ & 50 & 969 & 58 \\
\hline 2 & 1909 & 449 (23) & 42 & 802 & 56 \\
\hline 3 & 1940 & $457(23)$ & 34 & 660 & 69 \\
\hline 4 & 2018 & $286(14)$ & 26 & 525 & 54 \\
\hline 5 & 2035 & 264 (12) & 18 & 366 & 72 \\
\hline 6 & 1945 & $194(9)$ & 10 & 195 & 99 \\
\hline Total & 11,785 & $2213(18)$ & 30 & 3517 & 63 \\
\hline
\end{tabular}

${ }^{*}$ Calculated number susceptible $=$ number of students $\times$ per cent susceptible; ${ }^{\dagger}$ Estimated per cent of susceptibles immunized $=($ number immunized/calculated num ber susceptible) $\times 100$

\section{METHODS (PROGRAM IMPLEMENTATION)} School staff vaccine program

The program was designed to minimize concern about the transmission of the vaccine virus to susceptible women of childbearing age who might be pregnant during the immunization program $(9,10)$. A letter was sent to all female school staff members, and an announcement was placed in all provincial newspapers describing the vaccine program and offering testing for immunity to chickenpox to any staff member without a history of the disease and who might become pregnant in the future. Those who contacted the Department of Health and Social Services and were eligible were sent a requisition for testing and were directed to the nearest hospital laboratory.

\section{School vaccine program}

A vaccine workshop for Public Health Nurses who administered the vaccine was held, and a fact sheet describing the vaccine and a consent form were sent to parents of all students in grades one to six before the clinics started. All students who had not had a history of chickenpox were offered the vaccine; no testing for immunity was done for students. Clinics were conducted by Public Health Nurses in 51 schools during 18 school days in the six-week period between February 23, 2000 and March 31, 2000.

\section{Media strategy}

The varicella immunization program was first announced in the legislature. Press releases informed the public before each phase of the vaccine program was initiated. On launching the program, a parent whose child had previously experienced severe chickenpox hepatitis was interviewed on television and she expressed her support for the availability of the program. This interview provided the general public with a picture of how ill a child with normal immunity could become from chickenpox. These announcements stimulated media interviews regarding the status of the vaccine program for school staff and the forthcoming program for students in grades one to six. Newspaper advertisements were also released before each phase of the program. For the age 12 months to grade one program, a letter to the daycare facilities advised them of the availability of the vaccine and suggested that they recommend that parents take their children to the Public Health office to receive the vaccine.

\section{RESULTS AND OBSERVATIONS}

\section{Staff immunization program}

In the 51 grade one to six schools in PEI, there were 591 full time teachers and 53 secretaries/receptionists. The number of part-time teachers and volunteer resource teachers was not known. Thirty-two female staff members without a history of chickenpox agreed to be tested for immunity; 29 (90\%) were immune, one $(3 \%)$ was not immune, and two $(7 \%)$ were indeterminant. The vaccine was offered to and accepted by those who were not immune.

\section{Student immunization program}

Overall, $2213(18.8 \%)$ of the 11,785 students received the vaccine; the range of acceptance was from $29.1 \%$ in grade one to $9.8 \%$ in grade six (Table 1). The proportion of varicella-susceptible children who participated in the program is not known because parents were not asked to reply if they did not want their child to be immunized. Therefore, the distribution of nonparticipants between children already immune from previous infection and nonimmune children whose parents rejected immunization could not be determined.

By school entry, approximately $50 \%$ of Canadian children are immune to varicella; this increases to $90 \%$ by age 10 years and $95 \%$ by age 16 years (1-3). Using these Canadian seroepidemiological data and estimating an $8 \%$ acquisition of immunity to varicella per year between grades one and six, the proportion of susceptible children immunized by grade was estimated (Table 1 ). These estimates assume that only parents whose children were susceptible had their children immunized. Because a negative history of varicella does not always correlate with susceptibility, the proportion of susceptible children immunized may be overestimated. However, these data suggest that uptake of the vaccine by susceptible children was relatively uniform until the older grades, when uptake by susceptible children may have increased.

\section{Adverse reactions}

No active surveillance for adverse reactions was performed (11). Parents were requested to report any adverse reactions to their Regional Public Health Office. Many called to report a sore arm at the injection site. Six parents $(0.27 \%)$ reported a 
few lesions at the injection site, and five children $(0.23 \%)$ had lesions all over the body. One of those children with no history of exposure to natural chickenpox had extensive lesions six days after receiving the vaccine. Another received the vaccine five days after exposure to chickenpox and developed widespread chickenpox five days after immunization.

Only one serious adverse reaction was reported. One child, without known exposure to chickenpox, developed chickenpox lesions at the injection site seven days after administration, followed by a fever, headache and giant urticaria. The child made a complete recovery.

\section{Program costs}

The varicella vaccine was purchased at $\$ 51.75$ per dose, and the estimated administration cost was $\$ 5.00$ per dose. The cost of 32 staff members' serology was $\$ 850.00$ ( $\$ 25.00$ each), and the cost of the vaccine for the three staff members who received it was $\$ 340.50$. The testing program saved a total of 58 doses of vaccine, saving $\$ 2,441.50$. Other costs of the program included $\$ 6,457.06$ for advertising and public relations. The total estimated cost of this program from 2000 to 2002 inclusive was approximately $\$ 500,000$ to administer an anticipated total of approximately 9500 doses ( $\$ 51.75 /$ dose).

\section{Controversy regarding the vaccine}

Although there were questions and concerns generated by the media when the program was announced regarding the possible shift of the occurrence of the disease to nonimmune adults after the introduction of a varicella vaccine program, this did not appear to deter parents from having their children immunized. Because all children from age 12 months to those in grade six were offered the vaccine, the concern about the program shifting the disease to susceptible adults was reduced. A concern repeatedly expressed by parents during the school clinics was why preschool siblings could not be included in the school clinics.

\section{DISCUSSION}

The first phase of the PEI program to provide varicella vaccine to school-aged children was successfully implemented. Just less than $20 \%$ of school-aged children in grades one to six were immunized. Using Canadian seroprevalence data, we estimate that this was more than $60 \%$ of susceptible children. Offering testing to female staff members who had no history of chickenpox and who might become pregnant in the future was cost effective because nearly all the female staff members who were tested were immune. In addition, providing the female teachers and staff with testing and vaccination if they were not immune was welcomed by the schools and assisted in enhancing the cooperation of school staff in conducting the student clinics.

The media strategy was to promote interviews regarding the program. The cooperation of daycare facilities in recommending that parents bring in their children in the 12 month to grade one age range resulted in a notable increase in appointments to receive the vaccine. Perhaps most effective was the local parent who was interviewed when the program was initiated and who shared the personal experience of her child having been very ill with chickenpox. She encouraged parents in
PEI, as members of the public, to take advantage of the vaccine program. As a result, the major controversy during the school vaccine clinics came from parents who wanted the preschool siblings vaccinated at the same time as their school-aged children.

The rate of adverse reactions with active surveillance of chickenpox vaccine has been reported to be about 10 times higher than that in our program $(12,13)$, likely reflecting under-reporting in our passive system. It is likely that many reports of chickenpox lesions after receiving vaccine were caused by wild virus rather than the vaccine strain (14). Many children had far more than the usual upper limit of 50 vaccineassociated lesions typically seen during clinical trials (13). However, no viral studies were performed to confirm whether the lesions were wild or vaccine virus strains.

Jurisdictions interested in implementing a similar program will need to carefully consider the costs. The total estimated cost of the PEI varicella immunization program during the period of 2000 to 2002 inclusive was approximately $\$ 500,000$; however, additional funds may have further enhanced the program. With more resources, information on school-aged children who are not vaccinated could have been collected to better assess the success of the program and the reasons for nonparticipation. Also, a more active surveillance for adverse events and for 'breakthrough' cases of varicella would have provided further information on program effectiveness. Careful attention should also be given to address the parents' perspective (15). In summary, the varicella immunization program in PEI was designed to provide vaccine to susceptible children among the 11,785 students in grades one through six. Phase 2, a universal program for children 12 months of age, began April 1,2000 , and Phase 3 for those age 12 months to grade one was started in June 2000 and continued until 2002.

ACKNOWLEDGEMENTS: The authors thank the Public Health Nurses of the PEI Department of Health and Social Services for their dedication and hard work without which the varicella vaccine program would not have been possible. The cooperation of the principals, teachers and staff of the PEI schools is also gratefully acknowledged. We also appreciate the time spent by Dr Barbara Law, University of Manitoba, in reviewing this article.

\section{REFERENCES}

1. Law BJ. Towards universal childhood immunization against chickenpox? Pediatr Child Health 2000;5:262-6.

2. Ratnam S. Varicella susceptibility in a Canadian population. Can J Infect Dis 2000;11:249-53.

3. National Advisory Committee on Immunization. Statement on recommended use of varicella virus vaccine. Can Commun Dis Rep 1999;25(ACS-1):1-16.

4. Law B, MacDonald N, Halperin S, et al. The Immunization Monitoring Program Active (IMPACT) prospective five year study of Canadian children hospitalized for chickenpox or an associated complication. Pediatr Infect Dis J 2000;19:1053-9.

5. Laupland KB, Davies HD, Low DE, et al. Invasive group A streptococcal disease in children and association with varicella-zoster virus infections. <http://www.pediatrics.org/cgi/content/full/105/5/e60> Version current December 18, 2002

6. Law B, Fitzsimon C, Ford-Jones L, et al. Cost of chickenpox in Canada: Part I. Cost of uncomplicated cases. Pediatrics 1999;104:1-6.

7. Law B, Fitzsimon C, Ford-Jones L, McCormick J, Riviere M, members of the Immunization Monitoring Program-Active (IMPACT). Cost of chickenpox in Canada: Part II. Cost of complicated cases and total economic impact. Pediatrics 1999;104:7-14 
8. Health Canada. Proceedings of the National Varicella Consensus Conference. Can Commun Dis Rep 1999;25 (Suppl 5):1-25.

9. Salzman MB, Sharrar RG, Steinberg S, LaRussa P. Transmission of varicella-vaccine virus from a healthy 12 -month-old child to his pregnant mother. J Pediatr 1997;131:151-4.

10. Sharrar RG, LaRussa P, Galea SA, et al. The postmarketing safety profile of varicella vaccine. Vaccine 2001;19:916-23.

11. Committee on Infectious Disease. American Academy of Pediatrics. Varicella vaccine uptake. Pediatrics 2000;105:136-41

12. Black S, Shinefield H, Ray P, et al. Postmarketing evaluation of the safety and effectiveness of varicella vaccine. Pediatr Infect Dis J
1999;18:1041-6.

13. Shinefield HR, Black SB, Staehle BO, et al. Safety, tolerability, and immunogenicity of concomitant injections in separate locations of M-M-R-II, Varivax, and Tetramune in healthy children versus concomitant injections of M-M-R-II and Tetramune followed six weeks later by Varivax. Pediatr Infect Dis J 1998;17:980-5.

14. Johnson CE, Stancin T, Fattlar D, Rome LP, Kumar ML. A longterm prospective study of varicella vaccine in healthy children. Pediatrics 1997:100:761-6.

15. Kim MH. Chickenpox: A parent's perspective. Paediatr Child Health 2000;5:167-268. 


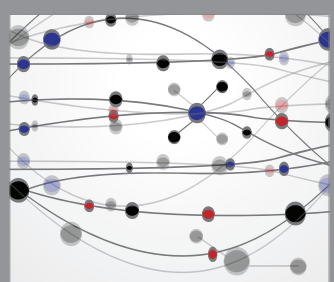

The Scientific World Journal
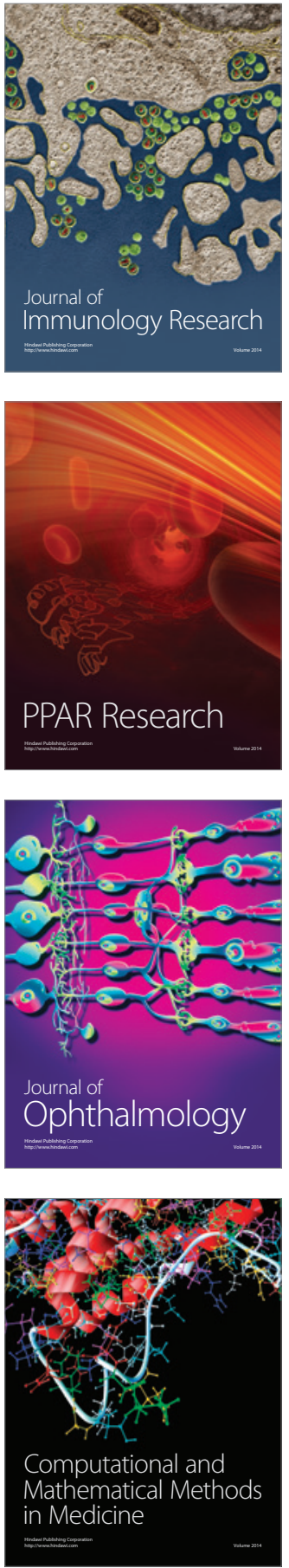

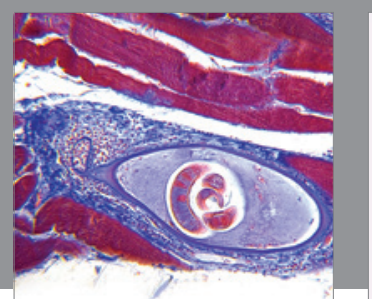

Gastroenterology Research and Practice

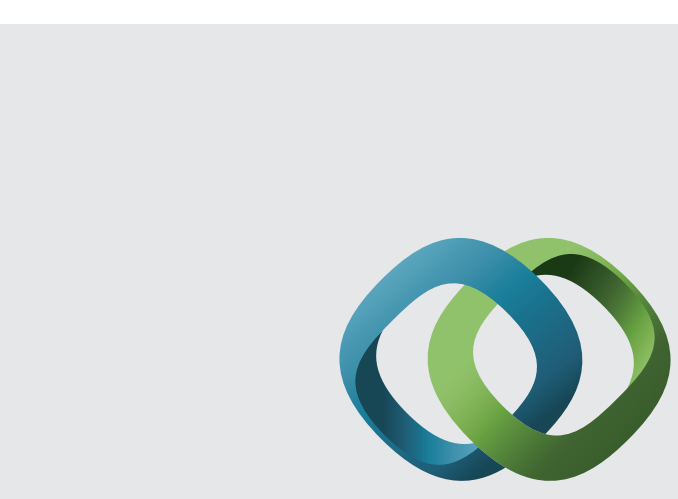

\section{Hindawi}

Submit your manuscripts at

http://www.hindawi.com
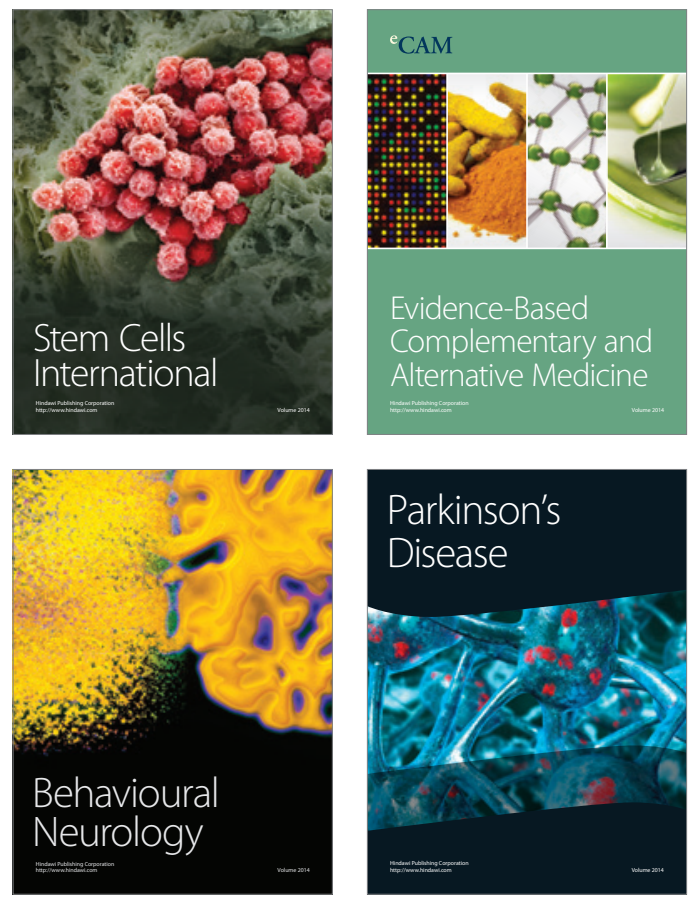
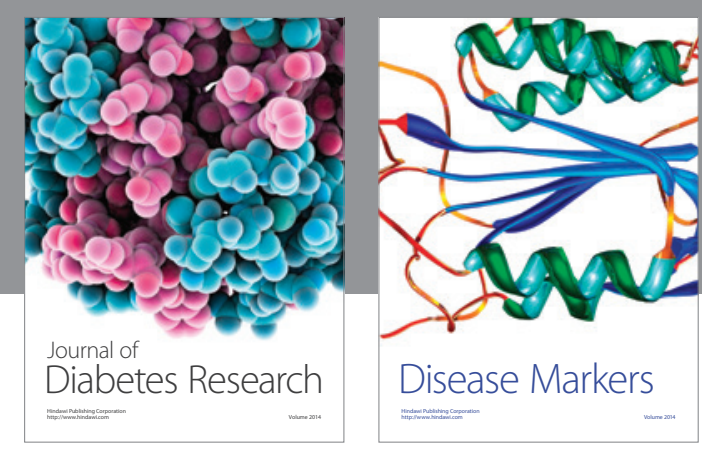

Disease Markers
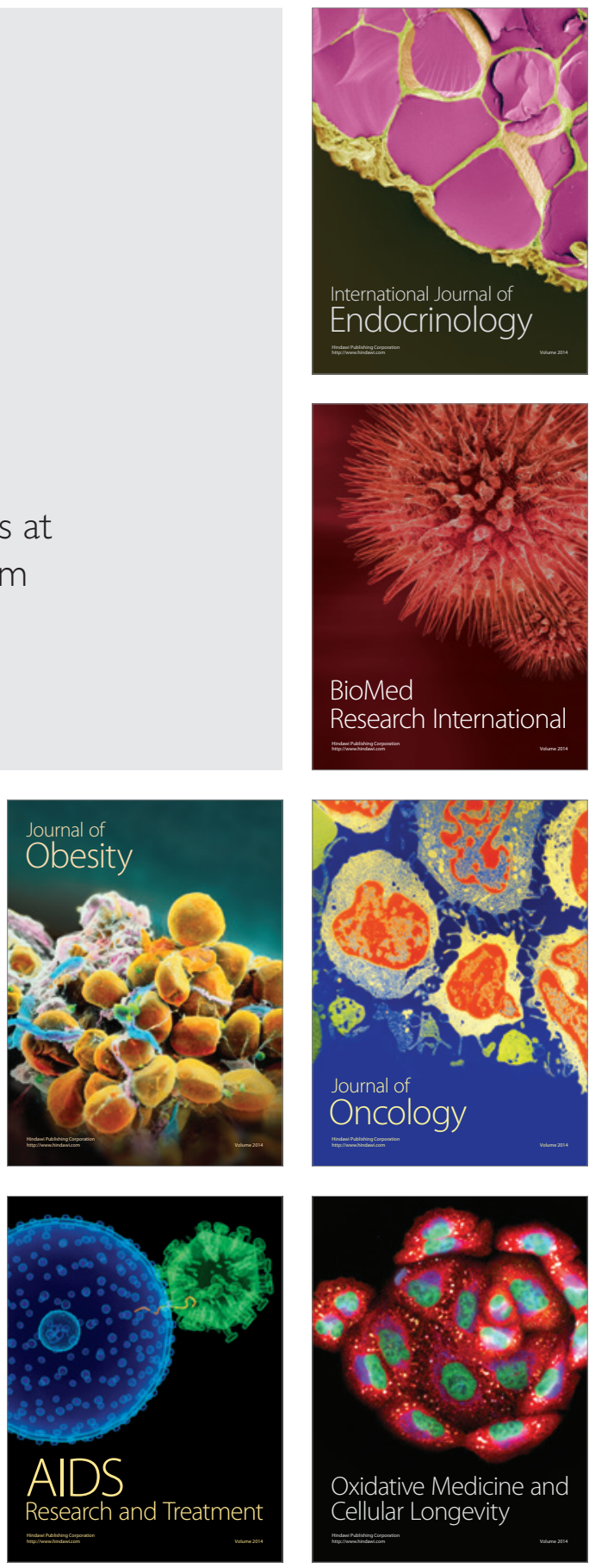